
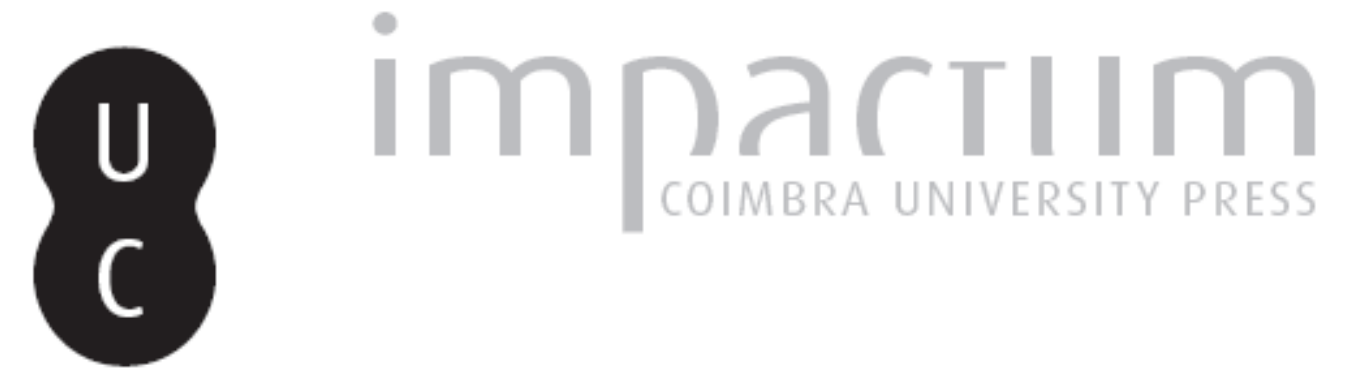

The reader makes the text: model readers on the move

Autor(es): $\quad$ Van Hoof, Lieve

Publicado por: International Plutarch Society

URL persistente:

URI:http://hdl.handle.net/10316.2/37611

DOI:

DOI:http://dx.doi.org/10.14195/0258-655X_3_7

Accessed : $\quad$ 26-Apr-2023 07:49:13

A navegação consulta e descarregamento dos títulos inseridos nas Bibliotecas Digitais UC Digitalis, UC Pombalina e UC Impactum, pressupõem a aceitação plena e sem reservas dos Termos e Condições de Uso destas Bibliotecas Digitais, disponíveis em https://digitalis.uc.pt/pt-pt/termos.

Conforme exposto nos referidos Termos e Condições de Uso, o descarregamento de títulos de acesso restrito requer uma licença válida de autorização devendo o utilizador aceder ao(s) documento(s) a partir de um endereço de IP da instituição detentora da supramencionada licença.

Ao utilizador é apenas permitido o descarregamento para uso pessoal, pelo que o emprego do(s) título(s) descarregado(s) para outro fim, designadamente comercial, carece de autorização do respetivo autor ou editor da obra.

Na medida em que todas as obras da UC Digitalis se encontram protegidas pelo Código do Direito de Autor e Direitos Conexos e demais legislação aplicável, toda a cópia, parcial ou total, deste documento, nos casos em que é legalmente admitida, deverá conter ou fazer-se acompanhar por este aviso. 


\section{PLOUTARCHOS, n.s.}

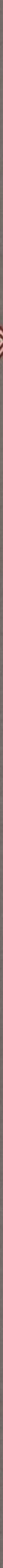

UNIVERSITY OF MÁLAGA (SPAIN)

UtAH STATE UNIVERSity, LOGAN, UTAH (U.S.A.) 


\title{
The Reader Makes the Text: Model Readers on the Move ${ }^{1}$ by \\ Lieve Van Hoof \\ K.U. Leuven, Belgium
}

\begin{abstract}
Plutarch and Seneca, with their works on anger, wanted to educate their readers on the subject. But who were they, these readers? This article examines and confronts the "model readers" of both works. It argues that Seneca's model reader belonged to the Roman elite, professionally busy with something else, but turning to philosophy in order to deal with anger in an appropriate way. Plutarch, on the other hand, wrote for Greeks and Romans who were or could be his friends, probably living an active life but interested in and familiar with philosophy throughout their lives

Of the writings composed in ancient Greece and Rome on the subject of anger, two have almost entirely come down to us: Seneca's On Anger (De ira $)^{2}$, and Plutarch's On the Control of Anger (Tie pi

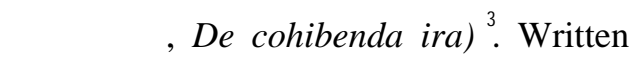
within sixty years from one another and rooted in the same tradition ${ }^{4}$, these works have much in common. Nonetheless, when reading them, one cannot but notice how different they actually are.
\end{abstract}

1 This article is an extended version of the paper "Plutarch's De cohibenda ira and its model reader", which I presented at the VIII Simposi Intemacional de la Societat Espanyola de Plutarquistes (IPS). Plutarc a la seva epoca: paideia $i$ societat, Barcelona (Spain), November 6-8 2003.1 wish to thank T. E. Duff, Ph. A. Städter, L. Van der Stockt, F. Titchener, and A. Zadorozhny for their stimulating responses to that paper.

2 Quotations and translations will be taken from J.W. Basore (ed.), Seneca. Moral Essays, Volume I (LCL), Cambridge, MA - London, 1994 [=1928].

3 We used the edition of M. Pohı enz (ed.), Plutarchi Moralia, Vol. Ill (BT), Leipzig, 1929. The translations were taken from W.C. Hel mbold (ed.), Plutarch. Moralia VI (LCL), Cambridge, MA - London, 2000 [=1939].

4 Both works have been subject to Quellenforschung. See, for example, M. Pohlenz, 1896, A. Schlemm, 1903, H. Ringeltaube, 1913, and P. Rabbow, 1914. On the question of the sources, see also D. Babut, 1969, H.D. Betz - J. Dillon, 1978, G. Cupaiuolo, 1975, J. Fil I ion-Lahil I e, 1984, and R. Laurent i - G. Indel I i, 1988. 
One of the differences concerns what Umberto $\mathrm{Eco}^{5}$ has labelled the "model reader", "a model of the possible reader supposedly able to deal interpretatively with the expressions in the same way as the author deals generatively with them". It is this aspect of the works which we intend to examine in the following pages. What readers did Plutarch and Seneca have in mind when writing the work? Whom did they want to convince? ${ }^{6}$

First of all, the texts contain some 'direct' indications as to whom they were intended for.

In On the Control of Anger, Plutarch does not act as spokesman himself. Formally, the work is a dialogue between two friends. Taking a look at their back grounds ${ }^{7}$, Sylla and Fundanus strikingly resemble each other in some aspects. Notwithstanding the Greek language of the dialogue, neither one of them is Greek. Sylla is originally a Carthagi nian, Fundanus springs of a Roman equestrian family, and both live in Rome (453 A). They both belong to a socio cultural elite, as can be derived, to name just one thing, from Fundanus' career ${ }^{8}$ and from Plutarch's judgement of Sylla's education ${ }^{9}$. Plutarch counts both Sylla and Fundanus among his friends. To the former he gave an important role in the dialogue On the Face in the Moon, to the latter in the work we are currently discussing. Both men seem to have been part of a Roman group of highly educat ed friends coming from diverse parts of the Roman world and meeting wherever they found themselves together ${ }^{10}$. A look

5 U. Eco, The Role of the Reader. Explorations in the Semiotics of Texts, Bloomington, 1979, p. 7. Eco underlines that the encyclopedic competence of the model reader is both presupposed and created by the text. The same applies to the moralism of the reader. See C.B.R. Pelling, 1995, "The Moralism of Plutarch's Lives", in: D.C. Innes, H.M. Hine \& C.B.R. Pelling, Ethics and Rhetoric. Classical Essays for Donald Russell on his Seventy-Fifth Birthday, Oxford, 205-220 (reprinted in C. B. R. Pel1ing, Plutarch and History, London, 2002, 237-251), p. 218: "There is evidently a two-way process here, with audience ready for the text, and the text affecting the audience."

6 Ancient readers really "made" texts, as I wrote in my title: "Ancient writers think of their work primarily in terms of persuasive presentation. The reference to the audience deter mines almost everything", Russe11, 1973, p. 162.

7 K. Ziegler, 1951, cols. 689-691, lists them both among Plutarch's most important Roman friends. Besides, for Sylla see Stein, "Sextius Sylla", RE Zweite Reihe, 4. Halbband, 1923, cols. 2051-2052. For Fundanus, see E. Gr o a g, 1932, cols. 1820-1826. 1821. On Fundanus, see also Jones, Plutarch and Rome, Oxford, 1971, pp. 57-58.

9 Rom. 15.

10 It is not sure whether this group should be seen as a circulus stricto sensu. E. Cizek, "La litterature et les cercles culturels et politiques ä l'epoque de Trajan", ANRW XXXIII. 1 
at the text On the Control of Anger shows that the work will have been appealing in the first place to this group of friends. They knew the people appearing in it and probably also the people Fundanus and Sylla were talking about, such as their common friend Eros and Fundanus' wife and daughters. Besides that, the text is teeming with ref erences to friendship, friends (453 A, $453 \mathrm{C}, 455 \mathrm{~B}, 455 \mathrm{C}, 459 \mathrm{C}, 460 \mathrm{E}, 460$ F, 461 A, 461 C, 461 D, 462 A, 462 E, $463 \mathrm{C}, 463 \mathrm{D}, 464 \mathrm{~A}$, and $455 \mathrm{~F})$, and all kinds of gatherings among them (453 A, $453 \mathrm{C}, 459 \mathrm{C}, 461 \mathrm{~A}-\mathrm{B}, 461 \mathrm{C}$, and 461 $\mathrm{D}-\mathrm{E})$. It is also implied in the text that these friends belong to an elite. Not only do they possess slaves (459 A, 459 B, 459 F, 460 A, 460 E, 460 F, 461 A, 461 B, $461 \mathrm{E}, 462$ A, $462 \mathrm{E}, 463 \mathrm{D}$, and 464

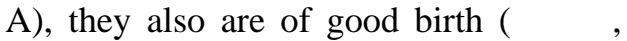
$453 \mathrm{~A})$, and can permit themselves to travel (453 C and $460 \mathrm{~F})$. We catch a glimpse of the fact that they may rule over others (462 A). Furthermore they have some interest in philosophy for they are wanting to engage in it in their

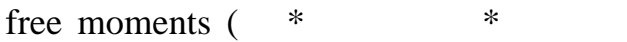
$\delta 1 \delta$ ovon , $453 \mathrm{C})$. They have a sense of morality ( $\varepsilon \tau \alpha v o \beta ı v, 460 \mathrm{C}$ ) and even a certain conception of themselves as an elite in some ethical way ( $\tau 01 * \kappa \alpha \lambda$ oi $\kappa \dot{\alpha} \gamma \alpha \theta \mathrm{ol} \kappa \tau \lambda .453 \mathrm{C}$ ). It is obvious that the more one shares with Sylla and Fundanus, the better will one be able to place oneself in their position and thus to understand what they are saying ${ }^{11}$. Sylla and Fundanus themselves, that is, those who know them and their friends, but also the broader group of people sharing their features.

If we try to determine the model reader of Seneca's work On Anger in the same way through direct indications, we see that Seneca wrote the work on demand of his brother Novatus. Novatus was making a career for himself and belonged to a socio-professional and therefore also economical elite. Seneca's text mentions slaves, clients, contacts with the mighty. When dealing with children's anger, it pays special attention to rich children and their educators. The text even explicitly talks about high offices, but it is not at all clear which office Novatus held at the moment. Judging seems to be mentioned quite often, but it is not really clear whether Seneca is talking about the tasks of a judge in Rome, or the act of judging as part of a proconsul's task. Besides, he also speaks about lawyers and talking in front of judges (2.17.1). Knowing or not

(1989), 3-35, esp. pp. 17-33, who examined the existence and importance of such cir culi, in his conclusion states that "il y en avait qui restaient en dehors des cercles cul turels et politiques [...] C'est peut-être aussi le cas de Plutarque” (v.c., p. 32). 
knowing Novatus and / or Seneca per sonally almost makes no difference to our understanding of the text, as it con tains nothing personal that could not belong to any other member of the elite. Seneca mentions "friends", but he does not seem to be thinking of any concrete friends of his brother's, let alone friends that he would know as well. Sylla and Fundanus, on the other hand, mention a friend of whom we know that other friends of Plutarch knew him as well ${ }^{12}$. Seneca mentions "slaves", but Funda nus talks about his own, individual slaves. Two passages about anger towards slaves who do not carry out well their job at the table may serve as an illustration.

Fundanus, in Plutarch's text, talks as follows:

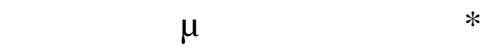

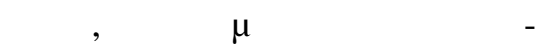

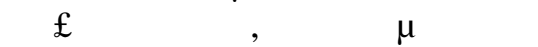

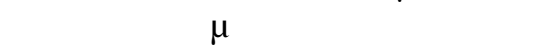

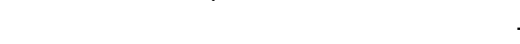

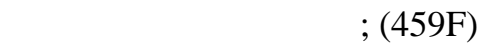

For which of us is so harsh that he scourges and chastises a slave because five or ten days ago he overroasted the meat or upset the table or came too slowly at our bidding? (459F) Conversely, Seneca fulminates like this: existence derive, in any society, from
Parum agilis est puer aut tepidior aqua poturo aut turbatus torus aut mensa neglegentius posita - ad ista concitari insania est. (2.25.1)

A slave is too slow, or the water for the wine is lukewarm, or the couch-cushion disarranged, or the tabel too carelessly set -it is madness to be incensed by such things. (2.25.1)

The things that go wrong at Fundanus' table are recounted by Plutarch as mini stories about a slave doing something wrong. The reader recognizes the situa tion either from Fundanus' or his own house: "which of us etc.". Through Plutarch's wording, the reader becomes a witness present when the little accidents happens. Seneca, on the other hand, men tions facts, without action and without even explicitly relating them to the slave who is responsible. The reader is kept at a more impersonal distance.

In the second place, the subject itself contains some information about the model reader: understanding a text about anger presupposes a reader who is in some degree familiar with that emotion. Anger is a universal phenomenon ${ }^{13}$, but it also is "a 'social construction,' in the sense that its modalities if not its very "our (ं่ $\dot{\omega} v)$ friend Eros". 
social structures and practices" 14 . Hence the question what kind of anger Plutarch and Seneca suppose their readers to be familiar with, and thus want to cure. Passages as the ones quoted above give an answer to this question.

Plutarch shows us people getting angry in various circumstances (460 F), but focuses on anger at home, directed towards slaves $(459 \mathrm{~A}, 459 \mathrm{~B}, 459 \mathrm{~F}-460$ A, $460 \mathrm{~F}, 461 \mathrm{~A}, 461 \mathrm{~B}, 461 \mathrm{C}, 461 \mathrm{D}$, $461 \mathrm{E}, 462 \mathrm{~A}, 463 \mathrm{~A}, 463 \mathrm{D}$, and $464 \mathrm{~A})$, friends (455 A, $455 \mathrm{C}, 455 \mathrm{~F}, 460 \mathrm{~F}, 461$ A, $462 \mathrm{~A}, 462 \mathrm{E}$, and $464 \mathrm{~A}$ ), and family (455 F, 457 A, 460 F, 461 A, 461 C, 462 A, 462 E, $463 \mathrm{E}$, and 464 A). Apart from some people who get angry out of hatred of evil, many are often offended by a sim ple word, a banal fact, or a trivial negli gence, and loose their self-control $(455 \mathrm{E}$, $455 \mathrm{~F}, 456 \mathrm{~B}, 456 \mathrm{C}$, and $459 \mathrm{~A})$ : they change physically ( $455 \mathrm{E}, 455 \mathrm{~F}$, and 456 C), they are not receptive of advice against the emotion (453 F - $454 \mathrm{~B}$ ), and they do (455 B, 457 A, $461 \mathrm{~A}$, and $462 \mathrm{E})$ and say (455 F and $458 \mathrm{D}$ ) terrible things. According to Plutarch, the underlying cause of many outbursts of anger is "self ishness and peevishness, together with luxury and softness"15.

All these elements recur in Seneca ${ }^{16}$. The Latin author, however, pays more attention to anger because of offences in public social life $(2.24 .1 ; 2.25 .4$; 3.31 .2 ), to the anger a judge can feel when exacting his function $(1.6 .1 ; 1.15 .1$ $3 ; 1.16 .1 ; 1.18 .1-2 ; 1.19 .5-7)$, and to col lective anger (3.2.2-3). On the whole, Seneca looks at the overall picture of the world with its mass of people doing bad things and considers it a place full of evil $(2.8 .3 ; 2.10 .2-4 ; 3.28 .1)$, at which people continuously get angry. Plutarch explicitly (463 D) denies such a pessimistic view. He prefers a smaller outlook, showing the people we spend most of our time with as human beings, with both positive and neg ative characteristics and acts, that is.
14

15

16

W.V. Har ris, 2002, p. 37.

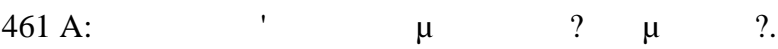

Anger in various circumstances: 3.8.4; 3.9.5. Anger towards slaves: 2.25.1; 2.31.2; $3.24 .2 ; 3.28 .1 ; 3.32 .1 ; 3.35 .2$. Anger towards friends: 2.31.2. Anger towards family members : 3.28.1; 3.41.3. Anger because of trivial offences : 1.1.2; 1.12.4; 1.18.2; $2.14 .4 ; 2.25 ; 2.26 .2 ; 3.8 .8 ; 3.29 .1-2 ; 3.30 .2 ; 3.32 .3 ; 3.34 .1-2 ; 3.35 .1 ; 3.35 .2 ; 3.35 .4-5$; 3.37.1-2; 3.38.1. Loosing one's self-control under the influence of anger : 1.1.2-4; $2.25 .1 ; 2.36 .6 ; 3.1 .5 ; 3.2 .5 ; 3.3 .6 ; 3.16 .2 ; 3.21 .5 ; 3.28 .1 ; 3.39 .4$. Physical changes : 1.1.2-4; 2.35.3-6; 3.4.1-3. Refuting advice during the outburst of the emotion: 1.7.2. Saying and doing terrible things: $1.1 .2-4$, respectively $2.36 .6 ; 3.2 .5 ; 3.3 .6 ; 3.41 .3$. Selfishness and luxury as underlying causes for anger : $2.25 .3-4 ; 3.12 .2 ; 3.40 .2$. As for anger out of hatred of evil, Seneca discusses many cases where someone gets angry at someone else's mistakes (peccata) (1.11.8; 1.14.1-3; 1.15.1; 1.16.1; 2.10.2; 2.31.83.25.2), but he has no specific term for it. 
Conversely, the proposed remedies also give information about whom the texts were intended for.

Plutarch wants to move his reader to gentleness $(\pi \rho \alpha \text { ó } \tau)^{17}$. But what exact ly does this mean for him? And what information can we derive from it about his model reader?

In the first paragraph, Sylla express es his admiration for Fundanus' becom ing more gentle. Both times he mentions the adjective ( $\pi \rho \dot{\alpha} о, 453 \mathrm{~B}$ and $453 \mathrm{C}$ ), he links it with the idea that Fundanus has made his temper obedient to reason. A dualistic conception of the soul is implied here, as in the rest of the work, although there is no theory or discussion of it. The first consequence of the being in control of reason, according to Fundanus, is that one is able to rein in and even eliminate angry actions and speech (454 E, 455 B). Throughout the work (453 B, 459 A-B and 460 A) it is stressed, however, that this does not result in an idle softness - an attitude, so we can conclude, which must have had a clearly negative connotation for Plutarch's readers. What is sometimes done in anger, can be done in a better way under the sway of reason. In this respect, Fundanus mentions brave acts (458 D-E) and the punishment of slaves (459 A-B). Apparently, Plutarch and his readers took punishing a slave who has done something wrong for granted. Reason being in control, not only will one be able to suppress the symptoms of anger, but also to fight against its causes. Not interpreting people's attitudes as despise or neglect, not giving in to self ishness and luxury, not expecting too much from others, and not being too curious will all help against anger. But there is more : these are steps towards gentleness, as Plutarch formulates it . This ideal of gentleness goes beyond a justice giving every person what is due to him. It implies not only avoiding to find out about the evil he commits, but also forgiving him when one has found out. Plutarch recognizes the possibility of anger out of true hatred of evil ( 100$\pi$ rovpia, $463 \mathrm{~B}$ and E), but his is a plea in favour of transcending even this justi fied anger (463 E). The inspiration to do so comes from an understanding of the human condition (463 E), combined with a humane benevolence ( $\varphi 1 \lambda \dot{\alpha} v \theta \rho \omega$ то , $464 \mathrm{D})$. With all this, it is clear that Plutarch does not just aim at diminishing anger. His ideal of gentleness comprises much more than the absence of the neg ative : it is a real, positive alternative for anger, an attitude in life that can over come that emotion (462 C). It goes with out saying that this is a far-reaching demand, not standing on its own but part

17 For the relationship between praotes and aorgesia in Plutarch, see F. Becchi, 1990, pp. 65-87. 
of a more general belief. Humane benevolence as a way of dealing with people is not something one gives proof of one moment to dismiss it the next. Therefore it is not likely that Plutarch's work On the Control of Anger was an interesting book for people who were not at all familiar with or interested in (practical) philosophy but wanted an $\mathrm{ad}$ hoc solution for the one emotion the work deals with. This hypothesis is reinforced by the fact that quite some concepts and ideas are mentioned but are not explained in the text ${ }^{19}$, suppos ing a reader to some degree familiar or wanting to become so with the philo sophical tradition and some other works of Plutarch's.

What about Seneca and his work $O n$ Anger? Seneca's goal is to eradicate anger, and he justifies (1.5.2-1.21.4, especially 1.7 and 1.8 .3 ) why it is so. The ideal situation is the Wise man's, who is not subject to the emotion of anger. Living in a world full of evil, he may feel something (1.16.7) when con fronted with the world, but he will not experience anger. As the author himself suggests (2.10.6), however, most people never attain this ideal situation. These people should try to diminish and con trol their anger as much as possible.

Like Plutarch, Seneca does not so much condemn every form of punishing wrongdoers, but rather makes a plea for doing so under the guidance of reason instead of anger. The attitudes for con quering anger that were mentioned when discussing Plutarch hold for Seneca as well, but the Latin author does not term them steps to anything more than the eradication of anger.

A major difference occurs when we confront what both authors say on the subject of anger out of hatred of evil. We already saw that Plutarch believed in such a kind of anger. Apparently, there were people in his and Fundanus' world who were moved by genuine hatred of evil, as was the case with their friend Eros (453 B). It should be noted, however, that Plutarch dedicates only the last paragraph to this subject. The author explicitly warns against a euphemistic abuse of the con cept (456 F and $462 \mathrm{E}$ ), and dedicates much more space to less justifiable anger. Seneca talks about anger because of trivial irritations as well, but goes more deeply into what seems to many a justifiable kind of anger. The world according to Seneca being a place full of evil, though, one should abstain from get ting angry at it sometimes in order to avoid doing so infinitely. Considering the mass of evil in the world and the evil char acter of men will help to attain this aim. On the other hand, all people are part of a big, cosmopolitan family among which it 
is natural for love to rule (1.5.2-3, 2.31.7, and 3.5.6), and therefore being angry at one another means breaking the laws of nature. Love is thus brought up by Seneca as an argument against anger, not as an atti tude to life. The difference in approach is significant. Seneca's work On Anger does not suppose its reader to lead a philosophi cally inspired life. It can be interesting as well for someone looking for help against the specific emotion of anger.

Plutarch and Seneca both have some ideas they want to promote, and those ideas, as we have seen, give information about who are the readers to be con vinced. The same goes for the means they use in order to do so.

To begin with, there are the argu ments used for promoting the ideas. Plutarch shows the disadvantages and dangers of anger and the contrary about gentleness $(456 \mathrm{E}, 458 \mathrm{C}, 458 \mathrm{E}, 458 \mathrm{~F}$, 459 A, 459 B, 459 C, 459 E, and 462 C): his readers to some degree or other must be pragmatic and interested in their own profits. They must also care about their reputation, as Plutarch often stresses the impact one's attitude towards anger may have on it $(455 \mathrm{E}, 458 \mathrm{D}, 455 \mathrm{E}-\mathrm{F}, 456$ $\mathrm{C}$, and $456 \mathrm{D})^{20}$. Apparently his readers also must have had a sense of etiquette (453 C, 455 E-F, 456 B, 456 C, and 459
E) and social standards (456 F and 458 B) which should be maintained ${ }^{21}$. They seem to have had some ethical concern as well (453 A, $454 \mathrm{~B}, 454 \mathrm{C}, 456 \mathrm{C}, 457$ A, $457 \mathrm{C}, 459 \mathrm{E}$, and $464 \mathrm{C}$ ), without neglecting the pleasure good things can provide (456 C, $461 \mathrm{C}, 462 \mathrm{~A}, 462 \mathrm{~B}, 462$ C, $464 \mathrm{C}$, and $464 \mathrm{D}$ ) for the person pos sessing them and the people around him. This last aspect is almost absent from Seneca's work On Anger, which sets more store by the unnaturalness of the emotion -a more theoretical argument. What Professor Ingenkamp has shown for Plutarch in comparison to Cicero, thus applies to Plutarch in comparison to Seneca as well: the Greek author uses more rhetorical arguments, the Latin author more philosophical ones.

This has brought us to the next point: the nature of the arguments that are brought up, and, connected with this, the structure and genre of the works. Seneca's work On Anger treats the sub ject in a linear, systematic way, which is underlined by structuring remarks at the beginnings and / or endings of the various parts. In a first step it defines anger, then it argues that the emotion is neither natu ral nor helpful. After that it demonstrates that it is possible to do something against the emotion, and finally it shows how this can be done in actual practice. This logi-

21 The importance of "Standesethik" has rightly been stressed by H.G. Ing e nk a mp, 2000, pp. 260-264. 
cal structure makes it stringent for one who has accepted the negative evaluation and the curability of anger to read the rest of the treatise and undergo the cure. But for that, it is necessary for each step to be cogent: if the reader is not convinced that anger should be eradicated, he will not be interested in reading that it is possible to do so, and if he does not believe that it is possible, he will not want to go on read ing how this works in actual fact. Therefore, Seneca must persuade his readers that his Stoic view is the right one, and he tries to do so by logical rea soning. What kind of model reader is all this suited for? Among Seneca's fellow "professional" philosophers, those lead ing a Stoic life will have accepted both his premises and his conclusions. No such extensive argumentation was neces sary for them, though. As for fellow pro fessional philosophers adhering to other schools, Seneca's work On Anger doesn't seem to be technical and thorough enough to be aimed at defying and con vincing them. On the other hand, the work must have been interesting for peo ple who were professionally busy with something else ${ }^{23}$, but for some reason decided they wanted to get rid of their anger and therefore turned to philosophy. Philosophers adhering to different philo sophical schools will have engaged in the battle to attain these people's attention. Seneca, raising Peripatetic objections and countering them explicitly with logical arguments, shows himself aware of this competition. The weapon he uses is a treatise on anger, limited to that topic but exhaustively dealing with it, which is per fectly understandable even for someone who is not acquainted with Stoic philoso phy at all, as all elements are explained and substantiated.

Plutarch's work On the Control of Anger, on the other hand, is a dialogue. The introduction depicts two friends undertaking a journey together, very similarly to some of Plato's introduc tions $^{24}$. Therefore it generates the expec tation not of a systematic philosophical treatise, but of a more or less realistic picture of some people discussing a philosophical problem. Reading on sup poses a reader who finds pleasure in reading and philosophizing, rather than one who wants to get the maximum profit - all relevant information - out of a minimal effort - reading as little as possible. The main part of Plutarch's work On the Control of Anger is an account both by and about a man of flesh and blood. It is a story about controling anger, not -or at least not explicit-

23 One of the people professionally busy with something else than philosophy whom Seneca may have had in mind is the Emperor Claudius. On this question, see G. Cupaiuol o, 1975, pp. 7-27. See also J. Fill ion-Lahil e, 1984, pp. 273-282, and eadem, 1989, pp. 1616-1619.

24 See the openings of the Phaedrus, of the Symposium, and also of the Republic. 
ly- a plea for it. The work contains no clear definition of anger, what is said is not placed in a philosophical system, an explicit rebuttal of other philosophers is equally lacking, and no clear structure is discemable. At least not at first sight. Taking a closer look, though, all elements of the traditional philosophical definition of anger appear to be present ${ }^{25}$. This sup poses a reader familiar with the philo sophical tradition, who will recognize Plutarch's hints and does not need more of a definition ${ }^{26}$. What is said is general ly understandable and valid only against a Platonic-Peripatetic background, which is supposed to be known, for not explained. Implicitly, Plutarch thus ${ }^{27}$ rejects the opinions of other schools, without doing a great effort at convincing any non-convinced. It is likely, therefore, that he was thinking of readers who could appreciate the philosophical tenor he himself avowed, as may have been the case for people knowing him and / or some of his other works. As for structure, the work is ingeniously composed so as to invite the reader to read story as plea, statements as exhortations : on the one hand, it affords the reader to observe Fundanus who first had a bad, but then acquired a good disposition concerning anger, on the other it has Fundanus say that his own amelioration began precise ly with the observation of people having such a bad disposition. In this way, the reader can identify himself with Fundanus. Two clues about the model read er can be derived from this. In the first place, the more the reader recognizes himself in Fundanus, the easier identifi cation will be. Conversely, Plutarch must have counted with a model reader resem bling Fundanus. Secondly, the identifica tion we described requires an experi enced reader, an intelligent reader read ing, rereading, and taking his time to let sink in what he reads ${ }^{30}$.

This hypothesis of Plutarch having in

Elements of a definition can be found in 454 F, 457 B, 460 D, 460 E, and 463 A. Even something close to a real definition is given, under the disguise of a metaphor in $457 \mathrm{~A}$.

${ }^{26}$ Compare Pelling, 2002, pp. 275-276, on the assumed literary culture of the narratee of the Lives.

27 The conception of the constitution of the soul, which we already referred to, is a clear example : utterances about a rational and an irrational part of the soul are in accordance with the Platonic-Peripatetic theory, and thus reject the Stoic conception of the soul. Applying the terminology suggested by C.B.R. Pelling, Plutarch. Life of Antony, Cambridge, 1988, p. 15, concerning moralism in Plutarch's Lives, one might say that his work On the Control of Anger is a work of descriptive rather than of protreptic moralism.

On the structure of On the Control of Anger, see also L. Van der St ockt, 2003, pp. 108, and 116.

30 Cf. Russe 1 , 1973,43: "Plutarch's appeal was to the highly trained, the imaginative, the leisured. He was not offering a short cut." 
mind a public of wide reading is con firmed by the fact that Plutarch's work $O n$ the Control of Anger contains some twen ty quotations from literary works, where as Seneca's work On Anger displays no more than five.

Last but not least, some external fac tors have a bearing on possible readers, and thus on the model reader.

Plutarch wrote his work On the Control of Anger in Greek. This lan guage was understandable for those whose native language was Greek, but also for most educated Romans. The persons of Sylla and Fundanus, Roman citizens having a conversation in Greek instead of Latin, which was their mother tongue, appear to be important once more: the fact that they are Romans may be seen as a clear sign for other Romans that this work was of interest to them as well, and not only to Greeks. In this respect, it is interesting to note that the anecdotes Plutarch recounts in the work are mainly about Greeks, though some times about Romans. The Roman exam ples were not numerous nor obscure ${ }^{31}$ enough so as to startle Greek readers, but will have particularly pleased Roman ones. As for the Greek examples, they must have sounded quite familiar to both Greeks and Romans. The latter is con firmed by the fact that Seneca, writing in Latin and therefore aiming mainly, if not exclusively, at a Roman audience ${ }^{32}$, used many of them as well.

Another question is whom the respective texts were concretely accessi ble for. Evidently, no precise answer to this question can be formulated, but it is possible to catch a glimpse on the basis of indications in the texts. Plutarch's work also being a homage to Fundanus and Sylla ${ }^{33}$, these people will no doubt have had a copy of it. The text not being too long, it may quite easily have been copied for some other members of the group of friends they and Plutarch belonged to. Further distribution of the text may have been brought about by these people in their turn, for example when visiting other friends in other cities. As for Seneca's work On Anger, the author himself as well as his addressee Novatus will have had a copy of it. Novatus may have shown it to friends of his who found themselves in the same sit uation as he when he asked his brother for the treatise. Those friends are likely to have belonged to at least a professional

31 The story about Porsenna and Mucius (457 F- 458 A) was a very well-known one, as Plutarch elsewhere notes (Life of Publicola, 17). Metellus (458 C) appears in Plutarch's collection of Sayings of Romans (202 A). As for Camillus (458 C), Marius (461 E) and Nero (461 E), Plutarch wrote works on their lives.

See J. Ka imio, The Romans and the Greek Language, Helsinki, 1979, p. 293 : "Rather few Greeks of the early Empire were able to read Latin literature, even if they were inter ested in doing so". 
elite. If the work through Novatus thus spread among the people working in the imperial administration, the top of this elite, the Imperial House itself, may have had knowledge of the work through the author himself and his career.

\section{Conclusion}

Seneca, so we can conclude, wrote for a professional, Roman elite. Although he was not on intimate terms with all mem bers of it, the author knew this class of people in general. They were people pro fessionally busy with something else than philosophy, not necessarily schooled in it, but ready to turn towards it when con fronted with a concrete problem : the con trol of their anger. The work he wrote for them, although containing a theory about anger, is a plea against the emotion, not a theoretical handbook about it.

Plutarch's model readers are to be found in concentric circles of friends : first Sylla and Fundanus, next the mem bers of the same group of friends, but by extension also these friends' - real or pos sible - friends. Plutarch wrote his work in Greek, but it is clear from the text that he did not see his model reader as necessar ily having that language as his mother tongue. Plutarch's model reader belongs to an elite, probably living an active live and therefore having down to earth con cerns. But at the same time he is educat ed, and so interested in and familiar with philosophy as to live a philosophically inspired life. We may even think of him as 'familiar with Plutarch', be it in person or through his works. With this work $O n$ the Control of Anger, Plutarch once again - the picture for the audience of the Lives bearing striking resemblance, as one can read in an article by Professor Stadter 3334 inspires these 'friends' for their lives, lives the author himself is likely to have been some part of ${ }^{35}$.

$$
\text { Sel ect ed Bibl iography }
$$

Ba but , D.,

- Plutarque et le stoïcisme, Paris, 1969.

Bec chi, F.,

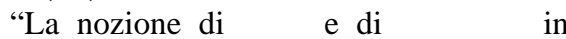
Aristotele e in Plutarco", Prometheus, 16 (1990) 65-87.

Be t z, H.D. \& Dil 1 o n, J.,

"De cohibenda ira", in: H.D. Betz (ed.), Plutarch's Ethical Writings and Early Christian Literature (Studia ad Corpus Hellenisticum Novi Testamenti, IV), Leiden, 1978, 170-197.

Cupaiuol o, G,

- Introduzione al De ira di Seneca (Studi e testi dell' antichità, I), Napoli, 1975.

Fil 1 ion-Lahil 1 e, J.,

- Le De ira de Sénèque et la philosophie stoïcienne des passions (Etudes et com mentaires, 94), Paris, 1984.

See R. Hir z e l, Der Dialog. Ein literarhistorischer Versuch, II, Leipzig, 1895, p. 170. 
Gr o a g , E.,

- "C. Minicius Fundanus", $R E \mathrm{XXX}$, 1932, cols. 1820-1826.

Ha r r is, W.V.,

- Restraining Rage. The Ideology of Anger Control in Classical Antiquity, Cambrid ge (Mass.) - London, 2002.

In g e $\mathrm{k}$ a mp, H.G.,

- Plutarchs Schriften über die Heilung der Seele, Göttingen, 1971.

- "Rhetorische und philosophische Mittel der Seelenheilung. Ein Vergleich zwis chen Ciceros Tusculaner Disputationen und Plutarchs Seelenheilungsschriften", in L. Van der Stockt, Rhetorical Theory and Praxis in Plutarch. Acta of the IVth International Congress of the International Plutarch Society, Leuven, July 3-6 1996, Leuven, 2000, 251-266.

La ur ent i, R. \& Inde11 i, G. (ed.),

- Plutarco. Sul Controllo delT Ira (CPM), Napoli, 1988.

Mar t in, H.J.,

- “The Concept of Praotes in Plutarch's Lives", GRBS, 3 (1960) 65-73.

Pel 1 ing, C.B.R.,

- '“You for Me and Me for You... '. Narrator and Narratee in Plutarch's Lives", in: C.B.R. Pel 1 ing, Plutarch and History. Eighteen Studies, London, 2002, 267-282.

POHLENZ, M.,

- "Ueber Plutarchs Schrift Tie pi $\dot{\alpha} о \rho \gamma \eta-$ oi $\alpha$ ", Hermes, 31 (1896) 321-338.

Rab bow, P,

- Antike Schriften über Seelenheilung und Seelenleitung auf ihre Quellen unter sucht, Leipzig-Berlin, Teubner, 1914.

Ringel t a u be, H.,

Quaestiones ad veterum philosophorum de affectibus doctrinam pertinentes, Gottingae, Diss., 1913.

Russe1 1, D.A.,

- Plutarch, London, 1973.

Schl emm, A.,

- "Ueber die Quellen des plutarchischen

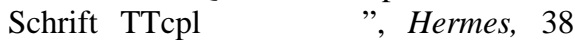
(1903) 587-607.

Van der St ockt, L.,

- "Odysseus in Rome. On Plutarch's Introduction to De Cohibenda Ira", Ploutarchos, n.s. 1 (2003-2004) 107-116.

Zie g 1 er , K.,

- "Plutarchos", RE XXI (1951), cois. 636962. 